\title{
Comparative Study of the Factors of Female Entrepreneurship in China and Pakistan
}

\author{
Rabia Gul ${ }^{1}$, Cisheng Wu${ }^{1 *}$, Barkat Ullah Khan² \\ ${ }^{1}$ School of Management, Hefei University of Technology, Hefei (HFUT), China \\ ${ }^{2}$ School of Public affairs, University of Science and Technology of China (USTC), Hefei, China \\ Email: *cswu@hfut.edu.cn
}

How to cite this paper: Gul, R., Wu, C. S., \& Khan, B. U. (2021). Comparative Study of the Factors of Female Entrepreneurship in China and Pakistan. Open Journal of Social Sciences, 9, 342-370. https://doi.org/10.4236/jss.2021.92024

Received: January 26, 2021

Accepted: February 21, 2021

Published: February 24, 2021

Copyright (c) 2021 by author(s) and Scientific Research Publishing Inc. This work is licensed under the Creative Commons Attribution International License (CC BY 4.0).

http://creativecommons.org/licenses/by/4.0/

(c) (i) Open Access

\begin{abstract}
Entrepreneurship has become very popular in the recent times and people are pursuing opportunities for new venture creation in different sectors. The phenomenon of "female entrepreneurship" is gaining wide popularity worldwide and now the interest of women in carrying out entrepreneurial activities is also increasing owing to the female empowerment in societies. The female entrepreneurs are highly affected by social, personality and institutional factors that motivate and encourage them in their entrepreneurial activities. The purpose of this study is to find out the impact of social support, financial support, entrepreneurial knowledge and achievement orientation on female entrepreneurial intention along with the mediating impact of entrepreneurial self-efficacy. For this purpose, the data was collected from 311 respondents from China and 311 from Pakistan through the administration of questionnaire. SPSS and AMOS were used for analysis and structural equation modelling has been used. The results have suggested that in case of China, all independent variables have significant impacts on female entrepreneurial intention but in case of Pakistan, financial support does not have the significant impact on female entrepreneurial intention. On the other hand, in case of China, the mediating role of entrepreneurial self-efficacy is significant in all cases, but in case of Pakistan, this mediating role is not significant in case of entrepreneurial knowledge.
\end{abstract}

\section{Keywords}

Social Support, Financial Support, Entrepreneurial Knowledge, Achievement Orientation, Entrepreneurial Intention, Entrepreneurial Self Efficacy

\section{Introduction}

Women have exhibited lower levels of attention towards the entrepreneurial se- 
tups, as compared to men, especially in the developing countries as this field is recognized more as a "male domain" (Malmström, Johansson, \& Wincent, 2017; Mehtap, Pellegrini, Caputo, \& Welsh, 2017b). However, the phenomenon of "female entrepreneurship" is gaining wide popularity worldwide and now the interest of women in carrying out entrepreneurial activities is also increasing owing to the female empowerment in societies (Paoloni \& Serafini, 2018; Pergelova, Manolova, Simeonova-Ganeva, \& Yordanova, 2019). In order to benefit from the women liberalization and empowerment, the talents of the females in their business venture must be created and polished (Wilson, Kickul, Marlino, Barbosa, \& Griffiths, 2009). Pakistan, being a developing country, has few numbers of jobs that can be offered to the fresh and unemployed young males and females of the country. Hence, engaging in entrepreneurial activities is the most viable solution (Iftikhar, 2016). According to a survey of the World Bank, Pakistan has a low ranking among the countries in which women are working as entrepreneurs (Mahmood, 2011). The latest figures show that the country has only $1 \%$ of female entrepreneurs, compared to the $21 \%$ of the male entrepreneurs. The survey also revealed that just $12 \%$ of firms in Pakistan have female owners and this ratio is $34 \%$ globally. Pakistan has high fertility rate and the working population of the country is projected to grow at $2.1 \%$ per year for the next ten years and the female labor force participation is $57 \%$ less than that the males. Even the job structure of Pakistan has proved to be static and though the youth is educated, still the employment outcomes are worse. This is characterized by high unemployment rate and youth bulge working in informal or unpaid jobs. According to Pakistan Update Development Report, the most viable solution for these issues is entrepreneurship by enhancing the productive and vibrant SME sector of the country so that more and better opportunities can be created for the women and the youth.

The state of female entrepreneurship in China is very prospective as the country has the highest number of successful female entrepreneurs in the world and China has also displayed an ideal model for the gender equality in the context of female entrepreneurship. The female entrepreneurs in China have built successful businesses there and the number of the female entrepreneurs has increased to $25 \%$ of the total entrepreneurs. Even the richest woman of the world is also a Chinese woman named Zhou Qunfei. However, women have also faced certain barriers there regarding the credit gap and the lack of formal financing required for the business. The government of China has improved the process of formal financing for females by strengthening the financial infrastructure. So, the female entrepreneurs face two major issues in China. The first obstacle is of tangible nature which implies the lack of financial and support network and secondly, the societal and the cultural obstacles which have been in the favor of men holding them fir for business and economic activities. Hence, it can be seen that in both the developing and developed countries, such as Pakistan and China, the female entrepreneurs face a similar kind of issues that can be dealt with 
to improve their entrepreneurial skills and behavior. Likewise, the Chinese government has been attempting to develop social networks, providing capital for the ventures and giving training to the women for building their entrepreneurial intentions.

On the basis of this discussion, the researcher has identified several factors that are major driver of the female intention for entrepreneurship. Among these determinants, the social and financial support build up the female entrepreneurial intention as the social support from people in the family, friends or colleagues can enable women share their work problems who can offer good advice or motivate them to meet the challenges bravely (Ahmad, 2011) and also improve their self-confidence. The absence of social support can discourage women and reduce their intention to undergo entrepreneurial activities (Minkus-McKenna, 2009; Noguera, Alvarez, \& Urbano, 2013). When the females are not equipped with accurate knowledge, then they can miss many business opportunities and not know how to handle them properly to avoid loss in business. Females with more knowledge of business and entrepreneurship are more confident (Roy \& Das, 2019) and will be able to start and manage their business in a profitable way (Hechavarria, Bullough, Brush, \& Edelman, 2019). Achievement Orientation is a personality trait that encourages the business women to work diligently in difficult and complex business situations and they will be able to fulfill their goals and targets while making un-due efforts, once they have determined their career choice. They can address to the competitive needs of the business while maintaining and gaining profits, improving the overall performance of business (Fairlie \& Holleran, 2012).

Hence, using the theories of "Guided behavior" and "Guided Preparation", proposed by (Ajzen, 2002), this study aims to provide an insight into the female entrepreneurial behavior and shall evaluate the factors of social support, financial support, entrepreneurial knowledge and achievement orientation as determinants of female entrepreneurial intention and analyze the role of entrepreneurial self-efficacy in these relationships and provide a comparative analysis of the female entrepreneurship in the context of China and Pakistan. This study ascertains that by ensuring the availability of social and financial support, provision of adequate knowledge of entrepreneurial techniques and building a sense of achievement in women can actually help them develop a self-confidence and self-efficacy from the perspective of entrepreneurship and with this their intention to join the business field as entrepreneurs will be fostered.

\section{Literature Review}

\subsection{The Theory of Guided Preparation (TGP)}

Depend on the observation that all types of entrepreneurs experience breaks in their knowledge and data mainly about the requirements for initiating a new profession or business, according to (Mao et al., 2018), the given theory of guided preparation gives a basis for effective as well as successful entrepreneur- 
ship practices. The current theory is found on the conception that the use of explicit as well as tacit data initiating mainly from contextual learning practices and also managed by effective and significant outside activities and factors can mainly offer the basis for victorious entrepreneurs (Corum, Corum, Pinzone Jr., Lilly, \& Wilson, 2018).

According to this theory, the knowledge support to entrepreneurs provides a significant source of successful entrepreneurs along with competitive advantage (Foran, 2016). The explicit knowledge support can mainly be saved and moved from one individual to another, which means it is effectively available to certain entrepreneurs, which directly affects the intentions of entrepreneurs. Additionally, this theory also states that an experienced individual could support entrepreneurs' attempts in the right path mainly by giving significant social as well as knowledge support and instructions to establish a new profession and business, to develop the entrepreneurial attempt more significant and favorable.

Nevertheless, the part of financial and achievement orientation has not been elaborately provided by the current theory. The female entrepreneur's practices have been limited to some uncertainty bearing and modern entrepreneur's professions and practices are different. Therefore, it is essential to develop an environment (especially in under-developed countries at different levels) to enable females to grow to become successful entrepreneurs with significant achievements.

\subsection{The Relationship between Social Support and Female Entrepreneurship Intention (FEI)}

Social support (SS) is generally identified as a basic component of favorable relationships and effective entrepreneurial intentions (Molino, Dolce, Cortese, \& Ghislieri, 2018). Necessarily, SS mainly involves having a mechanism of family and social peoples that an individual or female can turn to in times of requirement. Whether an individual facing personal challenges and require quick assistance or an individual wants to spend some time for a support on particular issue, according to Neneh (2020), these relationships and connections play a positive role in affecting the overall intentions of a person. It is SS that builds female up mainly during the times of stress about choosing the field of entrepreneurship and generally provides them the strength to make intentions and even thrive (Sahban, Ramalu, \& Syahputra, 2016). Empirical studies have also manifested the nexus between SS and entrepreneurial intentions and many different aspects of entrepreneurship in a different way (Khalid, Bashir, \& Saqib, 2018). Furthermore, social integration (SI) is an important aspect of SS which play a critical role in effecting FEI, because SI is the real participation in different social connections and this type of integration mainly involves emotions and sense of belonging to various social groups that directly affect entrepreneurial intentions (Farooq, 2018). The above relationship between SS and FEI is also supported by the theory of guided preparation, this is because the theory state that entrepreneurs need effective and strong SS for the successfulness in the field of entrepre- 
neurship and running a business. Therefore, depending on the above discussion the study proposes the following hypothesis:

H1: There is a positive relationship between social support and female entrepreneurial intention.

\subsection{The Relationship between Financial Support (FS) and Female Entrepreneurship Intention}

An empirical study by Mehtap, Pellegrini et al. (2017b), suggests that if females were provided the help they require to initiate a business, then they would implement innovation practices to develop essential modifications to the overall economy of the country. In general, though, males, as well as females, do not get equal chances in the field of entrepreneurship, and according to Lin, Lu, Hsieh, and Liu (2018), the issues regarding entrepreneurship are the same for both genders, but they are more important for women's, especially in Asian nations, where typically females entrepreneurs experience un-fairness and favoritism in the overall mechanism of initiating a new business (Sieger \& Minola, 2017). A greater proportion of the Asian female entrepreneurs depend majorly on financial support from their own economizing, family, and friends FS and a small number of loans from commercial banks. Financial support plays a huge role in starring a new business because according to Mehtap, Caputo, and Pellegrini (2017a), female entrepreneurs with a new business idea would mainly want to accumulate the entire essential resources majorly including capital and money to venture into the business as well as the market. FS is the part of the process, as certain businesses would need large start-up collections than single females would not have and these start-ups FS are necessary to kick-start a business concept because, without it, female entrepreneurs would not have the skills to carry out their ideas in the market and business world. Hence, giving access to FS will enhance many females' intentions to start up a new business concept. The above association between FS and EFI is also upheld by the theory of guided preparedness because of the theory manifest that the amount of FS and resources committed to a concept directly affect the development of new business and its related services. So, based on the above arguments the present research proposed the following hypothesis:

H2: There is a favorable relationship between financial support and female entrepreneurial intentions.

\subsection{The Interplay between Entrepreneurial Knowledge and Female Entrepreneurship Intention}

Entrepreneurial knowledge (EK) and female education across the Asian nations have not acknowledged the superiority it needs; therefore, most females do not have the required knowledge and abilities to start and run business (Ratten, 2016). Improper training and education have generated lots of issues for female entrepreneurs and when it comes to starting a new business, it evaluates the challenges certain female entrepreneurs experience in various economic aspects. 
Such as, mainly at the micro aspect, some opportunity issues are majorly due to lack of EK and education and short business experience (Meyer \& Hamilton, 2020). As a combined resource, EK designs and affects all the practices around the new business which certainly impacts the entrepreneurial intentions of females. According to $\mathrm{Wu}, \mathrm{Li}$, and Zhang (2019), EK can exist in different shapes such as tacit EK, explicit EK, and embedded EK. Tacit EK is a type of knowledge of personal know-how or ability rooted in practice and experience and this type of knowledge directly affects the intentions of females as entrepreneurs (Hutasuhut, 2018). EK has huge importance since it is inherently unique to a business because this type of knowledge directly shapes and derives the entrepreneurial intentions which further affect business activities and processes. Moreover, necessary entrepreneurial skills and information like financial management, communication and negotiation, and marketing sales and customer service (CS) also play a direct role in affecting the entrepreneurial intentions. The linkage between EK and EFI is also supported by the theory of guided preparation; as theory demonstrates that business knowledge plays an essential role in establishing successful business activities. Thus, depending on the above discussion the present research effort suggests the following hypothesis:

H3: Entrepreneurial knowledge positively relates to female entrepreneurial intention.

\subsection{The Relationship between Achievement Orientation and Female Entrepreneurship Intention}

According to Basardien, Friedrich, and Twum-Darko (2016) achievement orientation $(\mathrm{AO})$ refers to how a person interprets and reacts to certain tasks and challenges, resulting in different designs of cognition, behavior, and affect. Designed within a social cognitive model, achievement objective theory suggests that an individual's motivation and business achievement-related behaviors can mainly be determined by considering the reasons and objectives they adopt while engaged in business and entrepreneurial activities (Obschonka, Fisch, \& Boyd, 2017a). According to Saebi, Foss, and Linder (2019), the major focus is on how entrepreneurs think about their business, their responsibilities, and their business performance. AOs have been shown by different empirical studies such as Muralidharan and Pathak (2017) that demonstrate that AO is mainly related to the entrepreneur's business achievement and adjustment which impacts the intentions of entrepreneurs. Besides, motivation is a powerful instrument of AO which encourage entrepreneurs on daily basis by remembering business values and objectives and according to Uchenna, Sanjo, and Joseph (2019) motivation belongs to the self-management parts of EI, is the hidden factor that will encourage in achieving business goals and derive an entrepreneur to the final destination. The above theory of guided preparedness also supports the interplay between $\mathrm{AO}$ and FEI, the theory state that achievement motivation is the inner urge of an entrepreneur to attain something significant and unique to achieve a feeling of self-accomplishment and business satisfaction. These factors compli- 
cate as well as impede the overall intentions to start a business. Therefore, all the above discussion leads to the establishment of the given hypothesis:

H4: There is a favorable relationship between achievement orientation and female entrepreneur intention.

\subsection{The mediating role of Entrepreneurial Self-Efficacy in the Relationship between Social Support and Female Entrepreneurship Intention}

It has been stated by Neneh (2020) that entrepreneurial intentions were completely interceded by entrepreneurial self-efficacy. Opposite to desires, gender was not interceded by self-efficacy but had a coordinate impact such that females detailed lower entrepreneurial career eagerly. Khalid et al. (2018) elaborate that the probability of female entrepreneurial intention is adversely related to the need for social support. Bandura's social learning hypothesis highlights the impacts of role model on individual-level inclination to act on any specific task, and when the task is entrepreneurship, the influences of role model is epitomized. Female's social duty has been considered as that of a wife and a mother. Ahmed and Kayat (2019) describe that the female faces social dismissal in other zones of improvement, and this end has generally contributed to her being sidelined as a donor in national improvement. It has been proved by the theory of guided preparation the female entrepreneur's practices have been restricted to a few instabilities bearing, and present-day entrepreneur's callings and practices are distinctive due to no social and cultural support (Mwiya, Wang, Kaulungombe, \& Kayekesi, 2018).

Though it is difficult for females to work as an entrepreneur, it is fundamental to create an environment to empower females to develop to gotten to be effective entrepreneurs with noteworthy accomplishments. So, all the above discussion leads to the development of the following hypothesis:

H5: Entrepreneurial self-efficacy positively mediates the relationship between social support and FEI.

\subsection{The Mediating Impact of Entrepreneurial Self-Efficacy on the Relationship between Financial Support and Female Entrepreneurship Intention}

Nowiński, Haddoud, Lančarič, Egerová, and Czeglédi (2019) state that females are less slanted toward entrepreneurship when compared to their male partners. This truth is related to a complex mix of causes such as the conviction that enterprise maybe a male space, certain conditions inside the financial and social environment to succeeding in such exercises. Khalid et al. (2018) describe that raising capital is indeed more troublesome for women-owned businesses because mostly they don't get financial support from their family, and the investors don't cooperate with female entrepreneurs. So, due to the need for assets, female entrepreneurs turn to the banking framework to have the necessary resources to run their commerce. A pertinent stream of the literature contends that female 
entrepreneurs meet a few more monetary obstructions than male partners when looking for bank economics. The organizations managed by females are less likely to get a bank loan, and, however, when they succeed in borrowing, they are charged higher interest rates (Kumar \& Shukla, 2019). Liu, Lin, Zhao, and Zhao (2019) have found that less than $3 \%$ of companies with wander capital funding had female CEOs. It has been proved by the theory of guided preparation that financial activities have a positive impact on the success of an entrepreneur, and the practices of female entrepreneurs have been limited in the business. Consequently, the entire above discussion leads to the establishment of the following hypothesis:

H6: Entrepreneurial self-efficacy significantly mediates the linkage between financial support and FEI.

\subsection{The Mediating Role of Entrepreneurial Self-Efficacy in the Nexus between Entrepreneurial Knowledge and FEI}

An empirical study by Nowiński et al. (2019) manifests that, ESE is the intention of the confidence of the female entrepreneurs in them in their abilities and entrepreneurial skills before they launch out a business idea and innovation. According to Shahab, Chengang, Arbizu, and Haider (2019), ESE mainly initiates from the larger concept of self-efficacy (SE) embedded in the theory of social cognitive, which mainly used to reveals the importance of social factors, replication as well as observation of beliefs in social factors for the generation of SE thoughts. Moreover, self-efficacy, related to set up such as ESE, mainly has theoretical basics in the agency related to which entrepreneurs are indicated to interrelate collectively with external as well as internal conditions (Tsai, Chang, \& Peng, 2016). Hence, SE and its imitative indicated a process of behavior, agency, mental conditions, and deriving motivation which directly affects the intentions about entrepreneurship and starting a new business (Schmutzler, Andonova, \& Diaz-Serrano, 2019). The mediating impact of ESE on the nexus between EK and FEI is also upheld by the theory of guided preparedness, the theory describes that strong SE helps entrepreneurs to recover quickly from setbacks in starting a new business. Thus, based on the above discussion the current study suggests the following hypothesis:

H7: Entrepreneurial self-efficacy positively mediates the relationship between entrepreneurial knowledge and FEI.

\subsection{The Mediating Role of Entrepreneurial Self-Efficacy in the Association between Achievement Orientation and FEI}

Self-efficacy is the ability to measure the qualities and skills and abilities to perform a specific task (Stroe, Parida, \& Wincent, 2018). Self-efficacy is a key factor in the way of making progress and development and this helps in maintaining and leveling a business, management, and also to find innovations in the field of business and trade. The female is half of the total population of the world and this half of the total number of the population must be appreciated, encouraged 
and their abilities must be given high value and place to keep them very useful and influencing members in the field of business. Their self-efficacy will boost up and this plays a very positive role in the lives of females that they have played their role in the development of their family, country, and also to the world (Shi, Yao, \& Wu, 2019). Females must be encouraged not only in developed but in developing countries as well. A sustainable economy is possible through the means of equal performance from both gender forms. Therefore, based on the above arguments the given study recommends the following hypothesis:

H8: Entrepreneurial self-efficacy positively mediates the relationship between achievement orientation and FEI.

This research is based on the assumptions of the theories of "Guided behavior" and "Guided Preparation" to provide an insight into the female entrepreneurial behavior. According to this theory, support in the form of knowledge can be incorporated into the learning in such a way that can have a direct effect on the agent (Ajzen, 2002; Chrisman \& McMullan, 2004). Applying this theory to the thesis, it can be said that support and the knowledge factors can enable the female entrepreneurs to succeed in their entrepreneurial endeavor. The theory of "guided behavior" indicates that the behavior of an individual is guided by his/her perceptions about a certain situation (Hunjra, Ahmad, \& Niazi, 2011). In the light of these two theories, it can be stated that the intentions and behavior of female entrepreneurs can be determined according to their perceptions of the support they are getting and they can be guided by the knowledge they have relating to entrepreneurship and this can be used to build their self-efficacy and intentions.

Scholars have illustrated the social and financial support to be major determinants of FEI. Interaction with people around is necessary when conducting any business. Social support from people in the family, friends or colleagues can enable women share their work problems who can offer good advice or motivate them to meet the challenges bravely (Ahmad, 2011). Lack of social support can discourage women and reduce their intention to undergo entrepreneurial activities (Minkus-McKenna, 2009; Noguera et al., 2013). Studies have proved that SS can positively predict the FEI (Al-Kwifi, Tien Khoa, Ongsakul, \& Ahmed, 2020; Sahban et al., 2016; Shiri, Mohammadi, \& Hosseini, 2012). (Brush \& Cooper, 2012; Welter \& Kolb, 2006) have put forward that if the females are provided with support in the form of finances, then they can easily open a business and can bring positive changes to the economy. Due to gender gaps and discrimination in many developing countries, females find it difficult to get loan from the banks, which restricts their activities to enter into or run a new business setup. (Al-Kwifi et al., 2020; Başçı \& Alkan, 2015; Samuel, Ernest, \& Awuah, 2013) have proved that FS can positively foster the FEI.

More determinants of FEI are EK and AO. EK is major determinant of building intention of female entrepreneurs (Lo, Sun, \& Law, 2012). When the females are not equipped with accurate EK, then they can miss many business opportunities and not know how to handle them properly to avoid loss in busi- 
ness. Females with more knowledge of business and entrepreneurship will be able to start and manage their business in a profitable way (Hechavarria et al., 2019). Study by (Roxas, Cayoca-Panizales, \& de Jesus, 2008) has proved that a positive relation exist between EK and FEI. The last determinant of FEI for this study is the AO, which is one of the personality traits that encourage the business women to work diligently in difficult and complex business situations and can address to the competitive needs of the business while maintaining and gaining profits. This can also improve the overall performance of business (Fairlie \& Holleran, 2012). Study has empirically proved that AO is positively linked to FEI (Roy \& Das, 2019).

\subsection{Theoretical Framework}

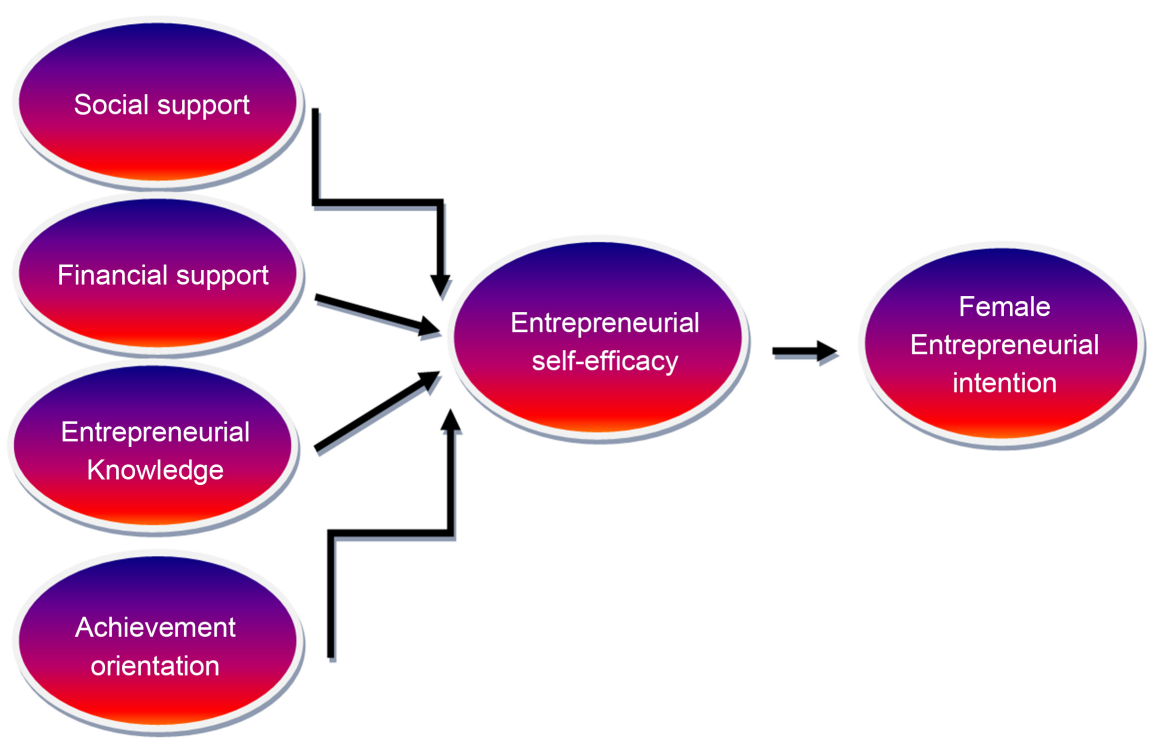

Research Framework.

The phenomenon of entrepreneurship and entrepreneur self-efficacy has been considerably gaining attention from the academic scholars since the past decade (Chan, Uy, Chernyshenko, Ho, \& Sam, 2015; Obschonka, Hakkarainen, Lonka, \& Salmela-Aro, 2017b). However, it is seen that even now a gender gap exist in the entrepreneurship as the number of women working as successful entrepreneurs, though, on the rise is still less as compared to men in this field (Al-Kwifi et al., 2020; Henry, Foss, \& Ahl, 2016; Roy \& Das, 2019) recommended that in order to address this gender gap, the contextual factors affecting the intention of females to start working as entrepreneurs need to be identified in detail. Since the studies on female entrepreneurship behavior are limited and sparse, hence research needs to be conducted on the females of the developing countries (Dvouletý, Gordievskaya, \& Procházka, 2018; Hussain \& Malik, 2018) testing the impact of social factors (Giménez \& Calabrò, 2018), entrepreneur self-efficacy (Mustafa, Hernandez, Mahon, \& Chee, 2016; Wang, Chang, Yao, \& Liang, 2016), support and knowledge relating to entrepreneurship (Saeed, Yousafzai, Ya- 
ni-De-Soriano, \& Muffatto, 2015) on the entrepreneurship intention. (Newman, Obschonka, Schwarz, Cohen, \& Nielsen, 2019) conducted an extant study to synthesize the empirically identified antecedents and consequences of self-efficacy of entrepreneurs and suggested further investigation into these variables by carrying outcross-country analysis.

\section{Methodology}

\subsection{Data Collection Procedure}

In the current study the researcher has collected quantitative data through survey questionnaire that contains various close ended questions. The close ended questions have been added because it will provide completely numerical or quantitative data that can be easily analyzed statistically. The questionnaire was self-administered so that the researcher might be able to clarify things for the respondents in case they face any ambiguity. The questionnaire was distributed among 325 respondents from China and same for Pakistan. After the collection of responses, 311 responses from China and 311 responses from Pakistan were considered as accepted for the analysis purpose and the remaining were discarded because either they were incomplete or the responses were not reliable.

\subsection{Instruments and Measures}

All the measurement items have been taken from the past studies that are reliable enough to be used in the study. These items have high values of reliability and all these scales have been established in previous studies. All of the items were measured on a 5-point Likert scale that record the responses on a continuum ranging from 1 to 5 with " $1=$ strongly disagree to $5=$ strongly agree". A 4 item scale adopted from Pruett, Shinnar, Toney, Llopis, and Fox (2009) and used by Al-Kwifi et al. (2020) was employed to measure the impact of social support. This scale had high reliability with value of 0.857 . A sample item is "My culture is not supportive of me and my business undertakings". The scale for measuring the effect of financial support was adopted from Pruett et al. (2009) and used by Al-Kwifi et al. (2020). This scale has highly reliability of 0.832 and comprises of total 4 items. One of the four items of this variable is "No discrimination procedures within banks to support female-run small businesses". For measuring entrepreneurial knowledge, scale was adopted from Dohse and Walter (2012) and Liñán, Rodríguez-Cohard, and Rueda-Cantuche (2011) and was used in recent study by Roy and Das (2019) was used. The scale had a total of 5 items and was higly reliable with a value of Cronbach's $\alpha$ of 0.74 . A sample item is "My only professional goal is to become an entrepreneur". Achievemnet orientation was measured with the 3-items scale of Lee and Tsang (2001) and used by Roy and Das (2019) in their recent study on entrepreneurship was employed. This scale is reliable with Cronbach's $\alpha$ is 0.73 . One of the three items of this variable is "I will not be satisfied unless I have reached the desired level of results". The entrepre- 
neurial self-efficacy was measured by adopting the 6-items scale of Marlino and Wilson (2003) and had been used in the studies of Wilson et al. (2009) with a high reliability of 0.830 . One of the six items of this variable is "Being able to solve problems". For measuring the responses to female entrepreneurial intention, the scale developed by Liñán and Chen (2009) and used recently by Roy and Das (2019) was employed. This scale has five items and has value of Cronbach's a more than 0.70 and hence, it is a reliable scale. One of the five items of this variable is "My only professional goal is to become an entrepreneur".

\subsection{Data Collection Method}

The data, for the purpose of research, were collected using the "survey method' through "questionnaires", structured on the already established scales for the measures from previous research studies.

\subsection{Variable Scales}

The following measurement scales were used in the study for the respective variables. All these scales have been established in previous studies and possess high values of reliability. These scales measure the responses of the sample participants on a 5-point Likert scale that record the responses on a continuum raging from 1 to 5 with " 1 = strongly disagree to $5=$ strongly agree".

\subsection{Social Support}

A 4 item scale adopted from (Pruett et al., 2009) and used by (Al-Kwifi et al., 2020) was employed to measure the impact of SS. This scale had high reliability with value of 0.857 .

\subsection{Financial Support}

The scale for measuring the effect of FS was adopted from (Pruett et al., 2009) and used by (Al-Kwifi et al., 2020). This scale has highly reliability of 0.832 and comprises of total 4 items.

\subsection{Entrepreneurial Knowledge}

For measuring EI, scale was adopted from (Dohse \& Walter, 2012) and (Liñán et al., 2011) and was used in recent study by (Roy \& Das, 2019) was used. The scale had a total of 5 items and was higly reliable with a value of Cronbach's a of 0.74 .

\subsection{Achievement Orientation}

AO was measured with the 3-items scale of (Lee \& Tsang, 2001) and used by (Roy \& Das, 2019) in their recent study on entrepreneurship was employed. This scale is reliable with Cronbach's $\alpha$ is 0.73 .

\subsection{Entrepreneurial Self-Efficacy}

The responses for the variable ESE were measured by adopting the 6-items scale 
of (Marlino \& Wilson, 2003) and had been used in the studies of (Wilson et al., 2009) with a high reliability of 0.830 .

\subsection{Female Entrepreneurial Intention}

For measuring the responses to FEI, the scale developed by (Liñán \& Chen, 2009) and used recently by (Roy \& Das, 2019) was employed. This scale has five items and has value of Cronbach's $\alpha$ more than 0.70 and hence, it is a reliable scale.

\subsection{Data Analysis Method}

The collected data was scrutinised for outliers or any missing values. They were treated so that the analysis data is free from any errors or missing numbers. Modern statistical techniques like the latest version SPSS and AMOS was used for analysis. The first step of the analysis was to run the descriptive of the data and the sample demographics. The reliability and validity were assessed with $\mathrm{KMO}$ to see if the sample is adequate for running principal component factor analysis. The reliability and validity were confirmed through Cronbach's $\alpha$, Convergent and Discriminate measures. SEM was done to examine the latent variables' causal relationships and establish model fitness using AMOS.

\section{Results}

Out of 311 females of the sample, $45.3 \%$ were past their bachelors, $36.7 \%$ had done masters and $18 \%$ had some other degree. The age of $30.9 \%$ individuals of sample was less than $25,41.8 \%$ of sample was between 25 to 35 years of age, $22.5 \%$ of sample was 35 to 45 years of age and $4.8 \%$ of the sample was more than 45 years of age. Experience of $14.8 \%$ of sample was less than 6 months, of $44.1 \%$ was between 7 to 12 months, of $31.5 \%$ was between 1 to 2 years and of $9.6 \%$ was more than 2 years. The demographical profile of Pakistan showed that, out of 311 females of the sample, $43.7 \%$ were past their bachelors, $36.0 \%$ had done masters and $20.3 \%$ had some other degree. The age of $34.1 \%$ individuals of sample was less than $25,38.9 \%$ of sample was between 25 to 35 years of age, $22.2 \%$ of sample was 35 to 45 years of age and $4.8 \%$ of the sample was more than 45 years of age. Experience of $23.8 \%$ of sample was less than 6 months, of $39.2 \%$ was between 7 to 12 months, of $28.6 \%$ was between 1 to 2 years and of $8.4 \%$ was more than 2 years.

From Table 1, the descriptive statistics of the data collected regarding the variables can be seen. Most of the values are skewed closer to the mean value and the standard deviation values are low, showing low deviation of the data from the mean value. Also, the value of standard error shows the difference between the sample mean and the population mean. So, in the present case, the values are low and equal to $13.8 \%$ merely, so it can be said that there lies a small difference between the sample and population mean. Showing that the sample represents the whole population accurately. 
Table 1. Descriptive statistics of china and pakistan.

\begin{tabular}{|c|c|c|c|c|c|c|c|}
\hline \multicolumn{8}{|c|}{ Descriptive Statistics of China } \\
\hline & $\mathrm{N}$ & Minimum & Maximum & Mean & Std. Deviation & \multicolumn{2}{|c|}{ Skewness } \\
\hline & Statistic & Statistic & Statistic & Statistic & Statistic & Statistic & Std. Error \\
\hline SociSupp & 311 & 1.00 & 5.00 & 3.4196 & 1.07349 & -0.415 & 0.138 \\
\hline FinanSupp & 311 & 1.00 & 5.00 & 3.3023 & 1.08782 & -0.326 & 0.138 \\
\hline AchievOrian & 311 & 1.00 & 5.00 & 3.2358 & 1.17017 & -0.300 & 0.138 \\
\hline EntrepKnow & 311 & 1.00 & 5.00 & 3.4939 & 1.18406 & -0.492 & 0.138 \\
\hline EntSelfEf & 311 & 1.00 & 5.00 & 3.3832 & 1.18311 & -0.451 & 0.138 \\
\hline FemEntInt & 311 & 1.00 & 5.00 & 3.5736 & 1.21717 & -0.591 & 0.138 \\
\hline \multicolumn{8}{|c|}{ Descriptive Statistics of Pakistan } \\
\hline & $\mathrm{N}$ & Minimum & Maximum & Mean & Std. Deviation & \multicolumn{2}{|c|}{ Skewness } \\
\hline & Statistic & Statistic & Statistic & Statistic & Statistic & Statistic & Std. Error \\
\hline SociSupp & 311 & 1.00 & 5.00 & 3.3151 & 1.07762 & -0.263 & 0.138 \\
\hline FinanSupp & 311 & 1.00 & 5.00 & 3.3424 & 1.02906 & -0.387 & 0.138 \\
\hline AchievOrian & 311 & 1.00 & 5.00 & 3.2358 & 1.17017 & -0.300 & 0.138 \\
\hline EntrepKnow & 311 & 1.00 & 5.00 & 3.5569 & 1.12247 & -0.534 & 0.138 \\
\hline EntSelfEf & 311 & 1.00 & 5.00 & 3.3832 & 1.18311 & -0.451 & 0.138 \\
\hline FemEntInt & 311 & 1.00 & 5.00 & 3.5736 & 1.21717 & -0.591 & 0.138 \\
\hline
\end{tabular}

Table 2 displays results for KMO and Bartlett's test, which checks adequacy and accuracy of the data. As far as these results are concerned, Kaiser-Meyer-Olkin Measure of Sampling Adequacy over here is to tell about any kind of variance that is present due to underlying factors, the value must be close to one and more than 0.8 , so the value of 0.938 for China and 0.936 for Pakistan is more than 0.8 obviously and is showing that the sample chosen was adequate and sampling was done adequately as well. Bartlett's Test of Sphericity is applied by the researcher to know about the state of the correlation matrix, it can be seen that the value for significance is equal to 0.000 which is less than 0.05 which means that the variables are interrelated and are good to go for further analysis.

Table 3 and Table 4 are showing the rotated component matrix which is also known to be as the factor loadings, it is the main output of the principal component's analysis. In it, the estimated correlations in between components and the variables is shown. In order to be strong, the correlation is supposed to be more than 0.7, it also shows that how much interrelated and codependent the variables are, the greater the codependency, All else of the values in the table of rotated component matrix for Pakistan and China is seen to have a factor loading of more than 0.7 , which makes the data reliable, adequately codependent, making a good set of variables and it also means all the indicators are eligible to added in further hypothesis testing, because all the factor loading are in suitable threshold level and all are in suitable and valid sequence and ranges. 
Table 2. KMO and Bartlett's test.

\begin{tabular}{cccc}
\hline & China & Pakistan \\
\hline Kaiser-Meyer-Olkin Measure of Sampling Adequacy. & 0.938 & 0.936 \\
\hline & Approx. Chi-Square & $11,056.974$ & $10,009.241$ \\
Bartlett's Test of Sphericity & Df & 351 & 351 \\
& Sig. & 0.000 & 0.000 \\
\hline
\end{tabular}

Table 3. Rotated component matrix of China.

\begin{tabular}{|c|c|c|c|c|c|c|}
\hline & \multicolumn{6}{|c|}{ Component } \\
\hline & 1 & 2 & 3 & 4 & 5 & 6 \\
\hline SS1 & & & 0.819 & & & \\
\hline SS2 & & & 0.897 & & & \\
\hline SS3 & & & 0.849 & & & \\
\hline SS4 & & & 0.818 & & & \\
\hline FS1 & & & & 0.865 & & \\
\hline FS2 & & & & 0.821 & & \\
\hline FS3 & & & & 0.826 & & \\
\hline FS4 & & & & 0.849 & & \\
\hline $\mathrm{AO} 1$ & & & & & & 0.803 \\
\hline $\mathrm{AO} 2$ & & & & & & 0.853 \\
\hline $\mathrm{AO} 3$ & & & & & & 0.827 \\
\hline EK1 & & 0.819 & & & & \\
\hline EK2 & & 0.828 & & & & \\
\hline EK3 & & 0.830 & & & & \\
\hline EK4 & & 0.865 & & & & \\
\hline EK5 & & 0.838 & & & & \\
\hline SE1 & 0.836 & & & & & \\
\hline SE2 & 0.805 & & & & & \\
\hline SE3 & 0.811 & & & & & \\
\hline SE4 & 0.847 & & & & & \\
\hline SE5 & 0.816 & & & & & \\
\hline SE6 & 0.787 & & & & & \\
\hline FE1 & & & & & 0.704 & \\
\hline FE2 & & & & & 0.695 & \\
\hline FE3 & & & & & 0.757 & \\
\hline $\mathrm{FE} 4$ & & & & & 0.754 & \\
\hline FE5 & & & & & 0.743 & \\
\hline
\end{tabular}


Table 4. Rotated component matrix of Pakistan.

\begin{tabular}{|c|c|c|c|c|c|c|}
\hline & \multicolumn{6}{|c|}{ Component } \\
\hline & 1 & 2 & 3 & 4 & 5 & 6 \\
\hline SS1 & & & & & 0.807 & \\
\hline SS2 & & & & & 0.879 & \\
\hline SS3 & & & & & 0.829 & \\
\hline SS4 & & & & & 0.780 & \\
\hline FS1 & & & & 0.849 & & \\
\hline FS2 & & & & 0.807 & & \\
\hline FS3 & & & & 0.815 & & \\
\hline FS4 & & & & 0.837 & & \\
\hline $\mathrm{AO} 1$ & & & & & & 0.793 \\
\hline $\mathrm{AO} 2$ & & & & & & 0.847 \\
\hline $\mathrm{AO} 3$ & & & & & & 0.821 \\
\hline EK1 & & 0.810 & & & & \\
\hline $\mathrm{EK} 2$ & & 0.814 & & & & \\
\hline EK3 & & 0.813 & & & & \\
\hline EK4 & & 0.880 & & & & \\
\hline EK5 & & 0.856 & & & & \\
\hline SE1 & 0.877 & & & & & \\
\hline SE2 & 0.848 & & & & & \\
\hline SE3 & 0.850 & & & & & \\
\hline SE4 & 0.887 & & & & & \\
\hline SE5 & 0.859 & & & & & \\
\hline SE6 & 0.832 & & & & & \\
\hline FE1 & & & 0.732 & & & \\
\hline FE2 & & & 0.730 & & & \\
\hline FE3 & & & 0.785 & & & \\
\hline FE4 & & & 0.778 & & & \\
\hline FE5 & & & 0.774 & & & \\
\hline
\end{tabular}

In Table 5, it can be seen that the value of CR for all of the variables is more than $70 \%$. On the other hand, the values of average variance extracted for all of the variables is more than $50 \%$ for all of the variables in both of the section of Pakistan and China which makes the data and results valid as well. Every variable has maximum loading with itself as compared to with others, so these validities prove the authenticity of collected data. And the results also show that the variables are adequately related and codependent on each other. 
The goodness fit index is more than 0.80 in both cases, and equal to 0.855 and 0.837 , the CMIN is less than 3 as required by the threhold level, the values for IFI are more than 0.90 and equal to 0.958 and 0.949 , CFI is also more than 0.90 and RMSEA is less than 0.80 , so all of the values of the compoenents are all right and valid according to the given threhold range, proving that there is a consistency of the researcher's understanding of nature of a construct with the measures of a construct. The CFA screenshots for China and Pakistan are given in Figure 1 and Figure 2.

SEM is given in Table 6 and Table 7. In case of Chinese females, the impact of social support on female entrepreneurial intention is significant and positive with a value of $27.1 \%$ which means that with 1 unit increase in social support female entrepreneurial intention will increase by $27.1 \%$, the impact of financial support is insignificant on female entrepreneurial intention, the impact of achievement orientation is significant and positive on female entrepreneurial intention and the impact of entrepreneurial knowledge on female entrepreneurial intention is significant and positive as well by a value of $19.4 \%$ which means that with every 1 unit increase in entrepreneurial knowledge, the female entrepreneurial intention will increase by $19.4 \%$. The mediation of Entrepreneurial Self-Efficacy between social support and female entrepreneurial intention is significant and positive, enhancing the relationship, the mediation of Entrepreneurial Self-Efficacy between Entrepreneurial knowledge and female entrepreneurial intention is significant and positive as well. And mediation in case of

Table 5. Convergent and Discriminant validity.

\begin{tabular}{|c|c|c|c|c|c|c|c|c|c|}
\hline \multicolumn{10}{|c|}{ China } \\
\hline & CR & AVE & MSV & SE & SS & FS & EK & $\mathrm{AO}$ & $\mathrm{FE}$ \\
\hline SE & 0.973 & 0.857 & 0.579 & 0.926 & & & & & \\
\hline SS & 0.959 & 0.854 & 0.445 & 0.583 & 0.924 & & & & \\
\hline FS & 0.949 & 0.825 & 0.325 & 0.570 & 0.484 & 0.908 & & & \\
\hline EK & 0.960 & 0.828 & 0.429 & 0.574 & 0.528 & 0.569 & 0.910 & & \\
\hline $\mathrm{AO}$ & 0.887 & 0.723 & 0.343 & 0.536 & 0.456 & 0.443 & 0.475 & 0.850 & \\
\hline $\mathrm{FE}$ & 0.971 & 0.871 & 0.579 & 0.761 & 0.667 & 0.544 & 0.655 & 0.586 & 0.933 \\
\hline \multicolumn{10}{|c|}{ Pakistan } \\
\hline & CR & AVE & MSV & SE & SS & FS & EK & $\mathrm{AO}$ & $\mathrm{FE}$ \\
\hline SE & 0.973 & 0.860 & 0.581 & 0.927 & & & & & \\
\hline SS & 0.930 & 0.769 & 0.341 & 0.438 & 0.877 & & & & \\
\hline FS & 0.941 & 0.799 & 0.341 & 0.457 & 0.584 & 0.894 & & & \\
\hline EK & 0.943 & 0.768 & 0.319 & 0.424 & 0.523 & 0.565 & 0.877 & & \\
\hline $\mathrm{AO}$ & 0.887 & 0.723 & 0.343 & 0.537 & 0.442 & 0.455 & 0.433 & 0.850 & \\
\hline $\mathrm{FE}$ & 0.971 & 0.871 & 0.581 & 0.762 & 0.541 & 0.495 & 0.534 & 0.586 & 0.933 \\
\hline
\end{tabular}




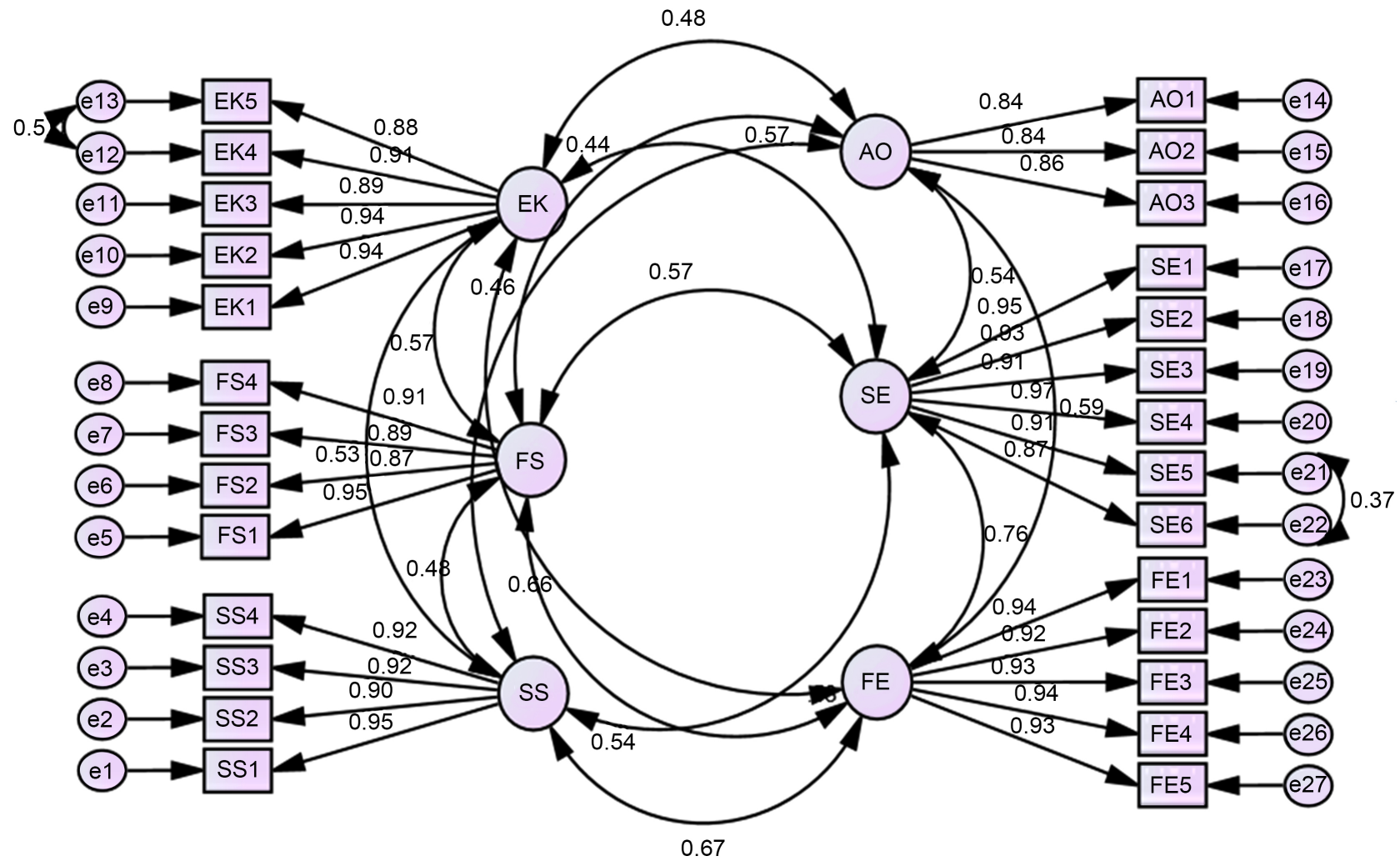

Figure 1. CFA China.

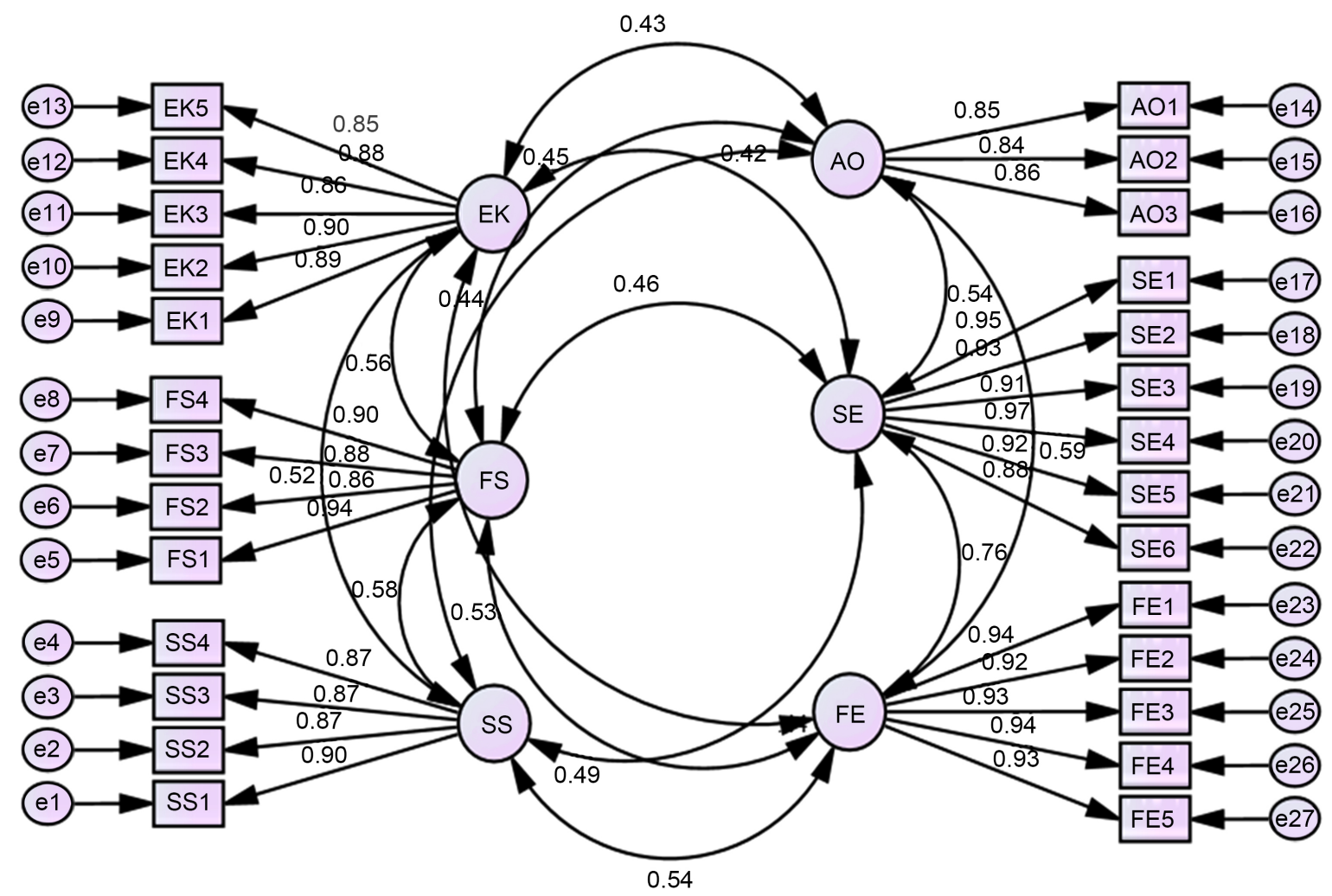

Figure 2. CFA Pakistan. 
Table 6. Structural equation modeling of China.

\begin{tabular}{cccccc}
\hline Total Effect & SociSupp & FinanSupp & AchievOrian & EntrepKnow & EntSelfEf \\
\hline EntSelfEf & $0.271^{* *}$ & $0.234^{* *}$ & $0.212^{* *}$ & $0.194^{* *}$ & 0.000 \\
FemEntInt & $0.346^{* *}$ & $0.110^{*}$ & $0.226^{* *}$ & $0.298^{* *}$ & $0.417^{\star *}$ \\
Direct Effect & SociSupp & FinanSupp & AchievOrian & EntrepKnow & EntSelfEf \\
EntSelfEf & $0.271^{* *}$ & $0.234^{* *}$ & $0.212^{* *}$ & $0.194^{*}$ & 0.000 \\
FemEntInt & $0.233^{* *}$ & 0.013 & $0.138^{*}$ & $0.218^{* *}$ & $0.417^{\star *}$ \\
Indirect Effect & SociSupp & FinanSupp & AchievOrian & EntrepKnow & EntSelfEf \\
EntSelfEf & 0.000 & 0.000 & 0.000 & 0.000 & 0.000 \\
FemEntInt & $0.113^{* *}$ & $0.098^{* *}$ & $0.089^{* *}$ & $0.081^{*}$ & 0.000 \\
\hline
\end{tabular}

Table 7. Structural equation modeling of Paksitan.

\begin{tabular}{cccccc}
\hline Total Effect & SociSupp & FinanSupp & AchievOrian & EntrepKnow & EntSelfEf \\
\hline EntSelfEf & $0.151^{* *}$ & $0.145^{* *}$ & $0.337^{\star *}$ & 0.119 & 0.000 \\
FemEntInt & $0.229^{* *}$ & 0.095 & $0.328^{* *}$ & $0.215^{* *}$ & $0.540^{* *}$ \\
Direct Effect & SociSupp & FinanSupp & AchievOrian & EntrepKnow & EntSelfEf \\
EntSelfEf & $0.151^{* *}$ & $0.145^{* *}$ & $0.337^{* *}$ & 0.119 & 0.000 \\
FemEntInt & $0.147^{*}$ & 0.017 & $0.147^{*}$ & $0.151^{* *}$ & $0.540^{* *}$ \\
Indirect Effect & SociSupp & FinanSupp & AchievOrian & EntrepKnow & EntSelfEf \\
EntSelfEf & 0.000 & 0.000 & 0.000 & 0.000 & 0.000 \\
FemEntInt & $0.081^{*}$ & $0.078^{*}$ & $0.182^{* *}$ & 0.064 & 0.000 \\
\hline
\end{tabular}

achievement orientation, financial support and female entrepreneurial intention is significant and positive as well. In case of Pakistani females, the impact of social support on female entrepreneurial intention is significant and positive with a value of $22.9 \%$ which means that with 1 unit increase in social support female entrepreneurial intention will increase by $22.9 \%$, the impact of financial support is insignificant on female entrepreneurial intention, the impact of achievement orientation is significant and positive on female entrepreneurial intention and the impact of entrepreneurial knowledge on female entrepreneurial intention is significant and positive as well by a value of $21.5 \%$ which means that with every 1 unit increase in entrepreneurial knowledge, the female entrepreneurial intention will increase by $21.5 \%$. The mediation of Entrepreneurial Self-Efficacy between social support and female entrepreneurial intention is significant and positive, the mediation of Entrepreneurial Self-Efficacy between Entrepreneurial knowledge and female entrepreneurial intention is insignificant. And mediation in case of achievement orientation, financial support and female entrepreneurial intention is significant and positive as well. Figure 3 and Figure 4 represent the SEM. 


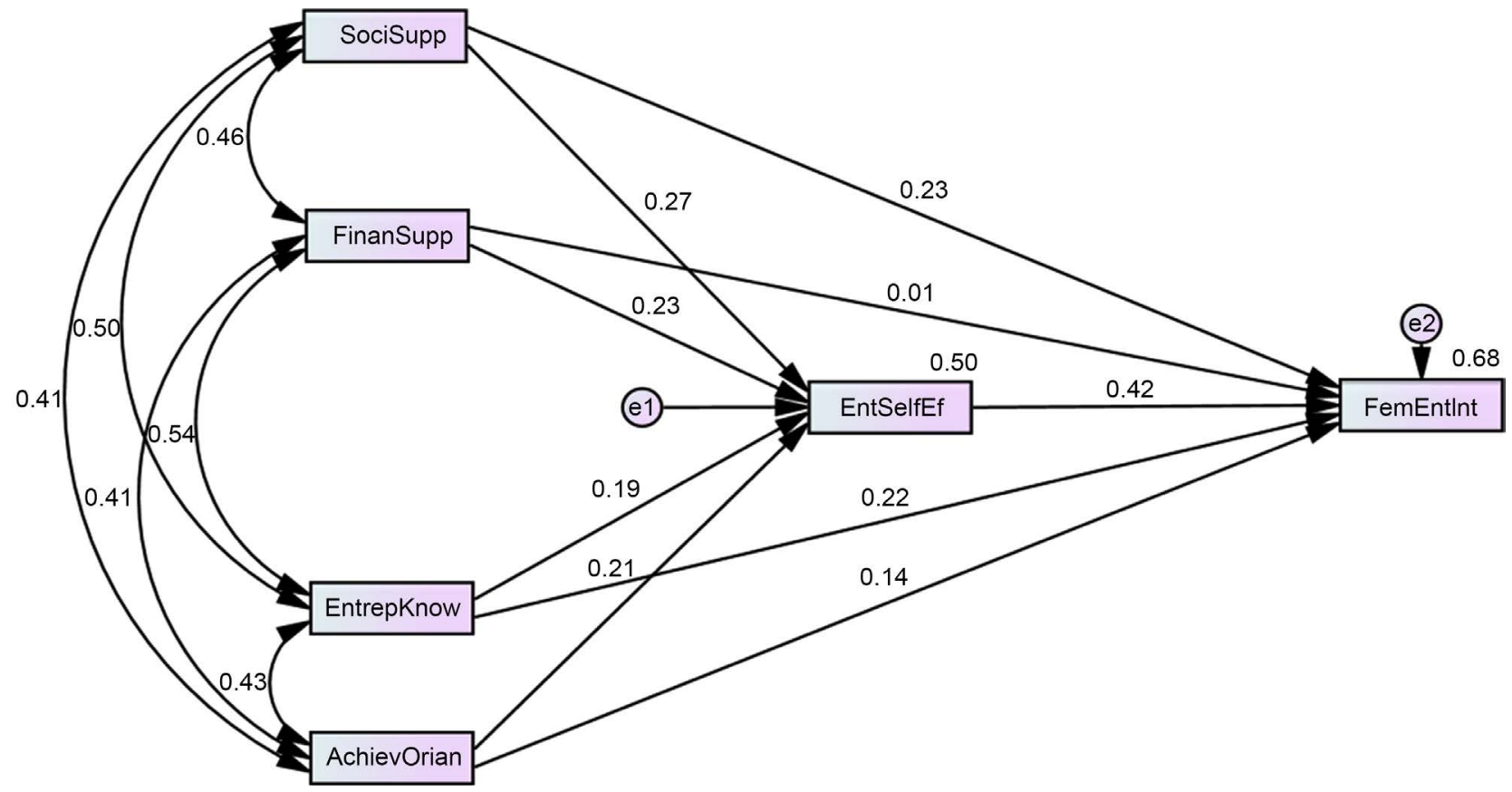

Figure 3. SEM China.

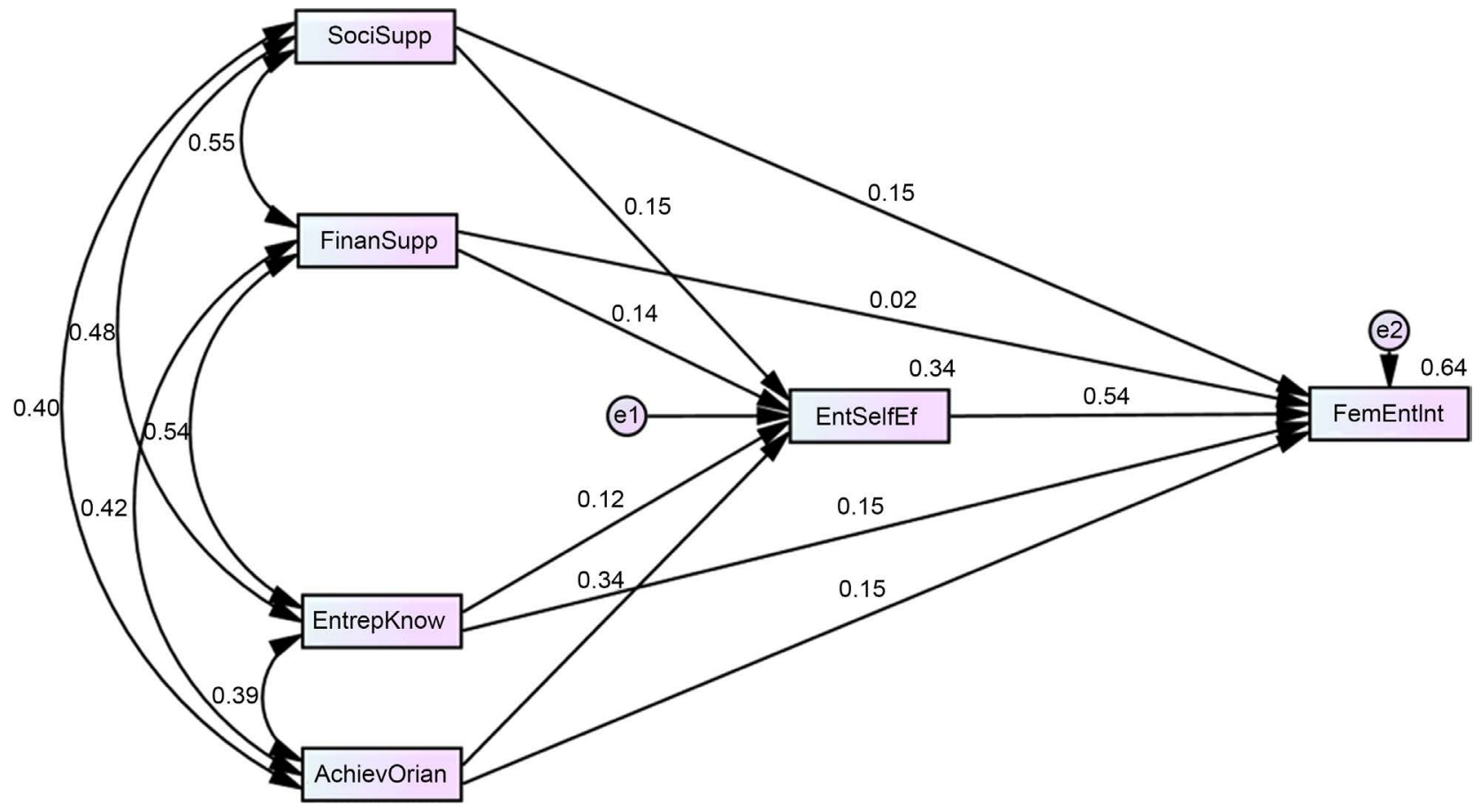

Figure 4. SEM Pakistan.

Table 8 is showing the extent of difference between variable impact results for China and Pakistan, it can be seen that value of significance for FE and SS is smaller than 0.05 which shows that the results are significantly different between China and Pakistan. Whereas, for FS, EK, AO and SE, the values are more than 0.05 which shows insignificant difference between results obtained for China and Pakistan. 
Table 8. Paired samples test.

\begin{tabular}{|c|c|c|c|c|c|c|c|c|c|}
\hline & & \multicolumn{5}{|c|}{ Paired Differences } & \multirow{3}{*}{$\mathrm{t}$} & \multirow{3}{*}{ df } & \multirow{3}{*}{ Sig. (2-tailed) } \\
\hline & & \multirow{2}{*}{ Mean } & \multirow{2}{*}{ Std. Deviation } & \multirow{2}{*}{$\begin{array}{l}\text { Std. Error } \\
\text { Mean }\end{array}$} & \multicolumn{2}{|c|}{$\begin{array}{l}95 \% \text { Confidence Interval } \\
\text { of the Difference }\end{array}$} & & & \\
\hline & & & & & Lower & Upper & & & \\
\hline Pair 1 & P_SS - C_SS & -0.10450 & 0.59698 & 0.03385 & -0.17111 & -0.03789 & -3.087 & 310 & 0.002 \\
\hline Pair 2 & P_FS - C_FS & 0.04019 & 0.48733 & 0.02763 & -0.01418 & 0.09457 & 1.454 & 310 & 0.147 \\
\hline Pair 3 & P_EK - C_EK & -0.01393 & 0.14962 & 0.00848 & -0.03063 & 0.00276 & -1.642 & 310 & 0.102 \\
\hline Pair 4 & P_AO - C_AO & 0.06302 & 0.58311 & 0.03307 & -0.00204 & 0.12808 & 1.906 & 310 & 0.058 \\
\hline Pair 5 & P_SE - C_SE & 0.01286 & 0.16400 & 0.00930 & -0.00544 & 0.03116 & 1.383 & 310 & 0.168 \\
\hline Pair 6 & P_FE - C_FE & 0.01994 & 0.17668 & 0.01002 & 0.00022 & 0.03965 & 1.990 & 310 & 0.047 \\
\hline
\end{tabular}

The research had the aim to know about the relationship between social support (SS) and female entrepreneurial intention (FEI), the relationship between financial support (FS) and female entrepreneurial intention (FEI), the relationship between Entrepreneurial knowledge (EK) and female entrepreneurial intention (FEI) and the relationship between Achievement Orientation (AO) and female entrepreneurial intention (FEI). Between these relations, the study also checked the mediation of Entrepreneurial Self-Efficacy (ESE). The researcher took a sample of 311 Chinese females and 311 Pakistani females, total sample was of 622 females and the demographical profiles of China were discussed.

\section{Discussion}

The study had the objective to know about the relationship between the factors affecting the female entrepreneurship intention. These factors were analyzed in the context of Chinese and Pakistani females separately. The female entrepreneurial intention is seen to enhance when social approval and support is there as well and it has also been seen in various studies done in China that $72 \%$ of the female population is self-efficient and self-made under the socially supported circumstances (Alon, Misati, Warnecke, \& Zhang, 2011). Entrepreneurship is mainly all about the execution of unique and naive idea and there are 101 ways in the book to generate resources and finance according to the rules of entrepreneurship. So, it can be asserted and exaggerated over here that other factors are more significant over here when it comes to female entrepreneurial intention and financial support has less direct influence over female entrepreneurial intention, it might or might not influence indirectly though (Deng, Wang, \& Alon, 2011). It has been observed according to a study that, the success rate of female entrepreneurs is higher in the females that are achievement oriented rather than the ones that do not have a clear goal or vision (Estrin \& Mickiewicz, 2011). It has been observed that females that have a clear goal and vision and are also always striving to achieve their goals and do everything in their possible ability to 
achieve what they believe in have a better female entrepreneurial intention (Hasan, 2020). Such females are observed to have a drive towards their goals and their female entrepreneurial intention is high enough to excel in their life in the pursuit of what they dream of and believe in. So, with the provided evidences, it can be said that the factor of achievement orientation enhances the female entrepreneurial intention in a positive and significant way to excel it $(\mathrm{He}, \mathrm{Lu}, \&$ Qian, 2019). The impact of entrepreneurial knowledge has been linked with entrepreneurial intentionIt is supported by a number of studies such as, the study of (Hernandez, Nunn, \& Warnecke, 2012), has suggested that in order to make and enhance intention regarding any kind of goal, or pursue any kind of dream, at the first place, it is necessary that the relevant knowledge and complete information regarding that step is acquired, this has proven to enhance the impact and the success rate by $75 \%$ more (Holmén, Min, \& Saarelainen, 2011). Also, a study has proven that not only in the case of female entrepreneurial intention but also in the case of other fields as well, the success rate is directly related with the relevant knowledge of the field. Female entrepreneurial intention can not only be enhanced in a significant and positive way with the help of relevant entrepreneurial knowledge but it can also enhance the rate of success of female entrepreneurs who take a decision to pursue their dreams that step towards being self-made with unique and out of the box ideas (Hussain \& Mahmood, 2012). In line with these studies and theirs the seven of the hypotheses were accepted whereas one was rejected according to the theory (Muhammad, Warren, \& Binte-Saleem, 2017), financial support and resources make the females self-efficient and increase their level of self-efficacy as well, all of which in turn enhances the possibility of increase in female entrepreneurial intention (Omeihe, Dakhan, Khan, Gustafsson, \& Amoako, 2019). Once the orientation towards goal is clear, the efforts become more vivid and are enhanced and then so it the goal for achieving an entrepreneurial dream becomes more important so female entrepreneurial intention clearly enhances (Ahmad, 2011). The relevant knowledge enhances the effectiveness of tasks, it can also make a person self-efficient in managing everything and get things done (Al-Sadi, Belwal, \& Al-Badi, 2011).

\section{Conclusion}

Aim of the study was to know about the relationship between social support (SS) and female entrepreneurial intention (FEI), the relationship between financial support (FS) and female entrepreneurial intention (FEI), the relationship between Entrepreneurial knowledge (EK) and female entrepreneurial intention (FEI) and the relationship between Achievement Orientation (AO) and female entrepreneurial intention (FEI). Between these relations, the study also checked the mediation of Entrepreneurial Self-Efficacy (ESE). The Chinese female data analysis is concerned, the results showed that the impact of social support, achievement orientation and entrepreneurial knowledge was significant on female entrepreneurial intention and the impact of financial support was insigni- 
ficant. Moreover, the mediation of entrepreneurial self-efficacy was significant in all of the cases as well. Whereas, where the results of the data analysis done with the data collected from the Pakistani females are concerned, the impact of social support, achievement orientation and entrepreneurial knowledge was significant on the female entrepreneurial intention, whereas, the impact of financial support was insignificant. Unlike China, the mediation was not significant in all of the cases, over here, the mediation was significant for all of the other relations except for the relationship between entrepreneurial knowledge and female entrepreneurial intention was not significantly mediated by entrepreneurial self-efficacy which is the case opposite to what was seen in the case of Chinese females.

\subsection{Implications}

The results of the study indicate that the societies and countries that want their female population to contribute to the economy, must extend their social support towards them, teaching the details and techniques of entrepreneurship can add up a great deal of knowledge to the making of a successful female entrepreneur. According to the results of the study, government of Pakistan and China and of any country that needs to promote female entrepreneurship, can take steps to improve the education facilities and knowledge campaigns regarding entrepreneurship for females, which will not only enhance their knowledge but will also impact their level of self-efficacy, also the study is promoting the societies to become a better place in which the element of support is the main factor that needs implementation.

\subsection{Limitations and Future Research Recommendations}

The researcher has chosen Pakistani and Chinese females as a sample and has then chosen data from random Pakistani and Chinese females who are new entrepreneurs, whereas, the researcher should have selected a specific sector for the purpose of data collection and should have specified their issues as well. The future researchers are recommended to select a specific group of entrepreneurs for the purpose of data collection that is most relevant to the field of entrepreneurship. Moreover, the researcher has only used the method of questionnaires or survey for the purpose of data collection in which not only the information can be biased but can also be filled with carelessness and the respondents might respond in a way that they really do not mean to. The future researchers are recommended to us the method of telephonic interviews along with the survey method so that a better and clearer picture can be obtained by the researcher regarding the problem.

\section{Conflicts of Interest}

The authors declare no conflicts of interest regarding the publication of this paper. 


\section{References}

Ahmad, S. Z. (2011). Evidence of the Characteristics of Women Entrepreneurs in the Kingdom of Saudi Arabia: An Empirical Investigation. International Journal of Gender and Entrepreneurship, 3, 123-143.

Ahmed, M. R. M., \& Kayat, K. (2019). Boosting Entrepreneurial Intentions among Female Tourism Students through Social Support and Entrepreneurial Self-Efficacy in Egypt: Can Entrepreneurship Education Moderate? Journal of Basic and Applied Research International, 25, 376-385.

Ajzen, I. (2002). Perceived Behavioral Control, Self-Efficacy, Locus of Control, and the Theory of Planned Behavior. Journal of Applied Social Psychology, 32, 665-683. https://doi.org/10.1111/j.1559-1816.2002.tb00236.x

Al-Kwifi, O. S., Tien Khoa, T., Ongsakul, V., \& Ahmed, Z. U. (2020). Determinants of Female Entrepreneurship Success across Saudi Arabia. Journal of Transnational Management, 25, 3-29. https://doi.org/10.1080/15475778.2019.1682769

Alon, I., Misati, E., Warnecke, T., \& Zhang, W. (2011). Comparing Domestic and Returnee Female Entrepreneurs in China: Is There an Internationalisation Effect? International Journal of Business and Globalisation, 6, 329-349. https://doi.org/10.1504/IJBG.2011.039391

Al-Sadi, R., Belwal, R., \& Al-Badi, R. (2011). Woman Entrepreneurship in the Al-Batinah Region of Oman: An Identification of the Barriers. Journal of International Women's Studies, 12, 58-75.

Basardien, F., Friedrich, C., \& Twum-Darko, M. (2016). Evidence-Based Practices of Promoting Entrepreneurship Education in Higher Education Institutions in Africa. Journal of Economics and Behavioral Studies, 868-81. https://doi.org/10.22610/jebs.v8i5(J).1432

Başçı, E. S., \& Alkan, R. M. (2015). Entrepreneurship Education at Universities: Suggestion for a Model Using Financial Support. Procedia-Social and Behavioral Sciences, 195, 856-861. https://doi.org/10.1016/j.sbspro.2015.06.364

Brush, C. G., \& Cooper, S. Y. (2012). Female Entrepreneurship and Economic Development: An International Perspective. Entrepreneurship \& Regional Development, 24, 1-6. https://doi.org/10.1080/08985626.2012.637340

Chan, K.-Y., Uy, M. A., Chernyshenko, O. S., Ho, M.-H. R., \& Sam, Y.-L. (2015). Personality and Entrepreneurial, Professional and Leadership Motivations. Personality and Individual Differences, 77, 161-166. https://doi.org/10.1016/j.paid.2014.12.063

Chrisman, J. J., \& McMullan, W. (2004). Outsider Assistance as a Knowledge Resource for New Venture Survival. Journal of Small Business Management, 42, 229-244. https://doi.org/10.1111/j.1540-627X.2004.00109.x

Corum, J. F., Corum, K. L., Pinzone Jr., B. F., Lilly, J. D., \& Wilson, S. W. (2018). Site Preparation for Guided Surface Wave Transmission in a Lossy Media: Google Patents.

Deng, S., Wang, X., \& Alon, I. (2011). Framework for Female Entrepreneurship in China. International Journal of Business and Emerging Markets, 3, 3-20. https://doi.org/10.1504/IJBEM.2011.037682

Dohse, D., \& Walter, S. G. (2012). Knowledge Context and Entrepreneurial Intentions among Students. Small Business Economics, 39, 877-895.

https://doi.org/10.1007/s11187-011-9324-9

Dvouletý, O., Gordievskaya, A., \& Procházka, D. A. (2018). Investigating the Relationship between Entrepreneurship and Regional Development: Case of Developing Countries. Journal of Global Entrepreneurship Research, 8, Article No. 16. 
https://doi.org/10.1186/s40497-018-0103-9

Estrin, S., \& Mickiewicz, T. (2011). Institutions and Female Entrepreneurship. Small Business Economics, 37, Article No. 397. https://doi.org/10.1007/s11187-011-9373-0

Fairlie, R. W., \& Holleran, W. (2012). Entrepreneurship Training, Risk Aversion and Other Personality Traits: Evidence from a Random Experiment. Journal of Economic Psychology, 33, 366-378. https://doi.org/10.1016/j.joep.2011.02.001

Farooq, M. S. (2018). Modelling the Significance of Social Support and Entrepreneurial Skills for Determining Entrepreneurial Behaviour of Individuals: A Structural Equation Modelling Approach. World Journal of Entrepreneurship, Management and Sustainable Development, 14, 242-266. https://doi.org/10.1108/WJEMSD-12-2017-0096

Foran, P. (2016). Undergraduate Surgical Nursing Preparation and Guided Operating Room Experience: A Quantitative Analysis. Nurse Education in Practice, 16, 217-224. https://doi.org/10.1016/j.nepr.2015.08.005

Giménez, D., \& Calabrò, A. (2018). The Salient Role of Institutions in Women's Entrepreneurship: A Critical Review and Agenda for Future Research. International Entrepreneurship and Management Journal, 14, 857-882.

https://doi.org/10.1007/s11365-017-0480-5

Hasan, S. M. (2020). Female Entrepreneurship: Do Urban Centers Ease out the Challenge? An Analysis for Pakistan. In M. Iftikhar, J. Justice, \& D. Audretsch (Eds.), Urban Studies and Entrepreneurship (pp. 163-179). Cham: Springer.

https://doi.org/10.1007/978-3-030-15164-5 9

He, C., Lu, J., \& Qian, H. (2019). Entrepreneurship in China. Small Business Economics, 52, 563-572. https://doi.org/10.1007/s11187-017-9972-5

Hechavarria, D., Bullough, A., Brush, C., \& Edelman, L. (2019). High-Growth Women's Entrepreneurship: Fueling Social and Economic Development. Journal of Small Business Management, 57, 5-13. https://doi.org/10.2139/ssrn.3460214

Henry, C., Foss, L., \& Ahl, H. (2016). Gender and Entrepreneurship Research: A Review of Methodological Approaches. International Small Business Journal, 34, 217-241. https://doi.org/10.1177/0266242614549779

Hernandez, L., Nunn, N., \& Warnecke, T. (2012). Female Entrepreneurship in China: Opportunity- or Necessity-Based? International Journal of Entrepreneurship and Small Business, 15, 411-434. https://doi.org/10.1504/IJESB.2012.046473

Holmén, M., Min, T. T., \& Saarelainen, E. (2011). Female Entrepreneurship in Afghanistan. Journal of Developmental Entrepreneurship, 16, 307-331.

https://doi.org/10.1142/S1084946711001860

Hunjra, A. I., Ahmad, H. M., \& Niazi, G. S. K. (2011). Planned Behavior Entrepreneurship and Intention to Create New Venture among Young Graduates. https://doi.org/10.2139/ssrn.1944685

Hussain, G. J., \& Mahmood, S. (2012). Impact of Microfinance Loan on Poverty Reduction amongst Female Entrepreneurship in Pakistan. Paper presented at the 2012 Cambridge Business \& Economics Conference, Cambridge, UK, 27-28 June 2012.

Hussain, S., \& Malik, M. I. (2018). Towards Nurturing the Entrepreneurial Intentions of Neglected Female Business Students of Pakistan through Proactive Personality, Self-Efficacy and University Support Factors. Asia Pacific Journal of Innovation and Entrepreneurship, 12, 363-378.

Hutasuhut, S. (2018). The Roles of Entrepreneurship Knowledge, Self-Efficacy, Family, Education, and Gender on Entrepreneurial Intention. Dinamika Pendidikan, 13, 90-105. https://doi.org/10.15294/dp.v13i1.13785 
Iftikhar, H. (2016). Pakistani Society Averse to Entrepreneurship. The Express Tribune.

Khalid, A., Bashir, M., \& Saqib, S. (2018). Collective Impact of Entrepreneurial Self-Efficacy and Risk Propensity on Entrepreneurial Intentions; Mediating Role of Perceived Social Support. International Journal of Engineering \& Technology, 7, 24-30. https://doi.org/10.14419/ijet.v7i3.21.17087

Kumar, R., \& Shukla, S. (2019). Creativity, Proactive Personality and Entrepreneurial Intentions: Examining the Mediating Role of Entrepreneurial Self-Efficacy. Global Business Review, online. https://doi.org/10.1177/0972150919844395

Lee, D. Y., \& Tsang, E. W. K. (2001). The Effects of Entrepreneurial Personality, Background and Network Activities on Venture Growth. Journal of Management Studies, 38, 583-602. https://doi.org/10.1111/1467-6486.00250

Lin, T.-L., Lu, T.-Y., Hsieh, M.-C., \& Liu, H.-Y. (2018). From Conception to Start-Up: Who and What Affect Female Entrepreneurship. Contemporary Management Research, 14, 253-276. https://doi.org/10.7903/cmr.17957

Liñán, F., \& Chen, Y.-W. (2009). Development and Cross-Cultural Application of a Specific Instrument to Measure Entrepreneurial Intentions. Entrepreneurship Theory and Practice, 33, 593-617. https://doi.org/10.1111/j.1540-6520.2009.00318.x

Liñán, F., Rodríguez-Cohard, J. C., \& Rueda-Cantuche, J. M. (2011). Factors Affecting Entrepreneurial Intention Levels: A Role for Education. International Entrepreneurship and Management Journal, 7, 195-218. https://doi.org/10.1007/s11365-010-0154-Z

Liu, X., Lin, C., Zhao, G., \& Zhao, D. (2019). Research on the Effects of Entrepreneurial Education and Entrepreneurial Self-Efficacy on College Students' Entrepreneurial Intention. Frontiers in Psychology, 10, 869. https://doi.org/10.3389/fpsyg.2019.00869

Lo, C., Sun, H., \& Law, K. (2012). Comparing the Entrepreneurial Intention between Female and Male Engineering Students. JWEE, No. 1-2, 28-51.

Mahmood, S. (2011). Microfinance and Women Entrepreneurs in Pakistan. International Journal of Gender and Entrepreneurship, 3, 265-274.

Malmström, M., Johansson, J., \& Wincent, J. (2017). Gender Stereotypes and Venture Support Decisions: How Governmental Venture Capitalists Socially Construct Entrepreneurs' Potential. Entrepreneurship Theory and Practice, 41, 833-860. https://doi.org/10.1111/etap.12275

Mao, L., Han, J., Zhao, D., Song, N., Shi, L., \& Wang, J. (2018). Particle Packing Theory Guided Thermal Conductive Polymer Preparation and Related Properties. ACS Applied Materials \& Interfaces, 10, 33556-33563. https://doi.org/10.1021/acsami.8b10983

Marlino, D. L., \& Wilson, F. (2003). Teen Girls on Business: Are They Being Empowered? Boston, MA: Simmons College School of Management.

Mehtap, S., Caputo, A., \& Pellegrini, M. M. (2017a). Encouraging Female Entrepreneurship in Jordan: Environmental Factors, Obstacles and Challenges. In V. Ramadani, L. P. Dana, S. Gërguri-Rashiti, \& V. Ratten (Eds.), Entrepreneurship and Management in an Islamic Context (pp. 207-225). Cham: Springer. https://doi.org/10.1007/978-3-319-39679-8 13

Mehtap, S., Pellegrini, M. M., Caputo, A., \& Welsh, D. H. B. (2017b). Entrepreneurial Intentions of Young Women in the Arab World: Socio-Cultural and Educational Barriers. International Journal of Entrepreneurial Behavior \& Research, 23, 880-902. https://doi.org/10.1108/IJEBR-07-2017-0214

Meyer, N., \& Hamilton, L. (2020). Female Entrepreneurs' Business Training and Its Effect on Various Entrepreneurial Factors: Evidence from a Developing Country. International Journal of Economics and Finance Studies, 12, 135-151. 
https://doi.org/10.34109/ijefs.202012109

Minkus-McKenna, D. (2009). Women Entrepreneurs in Riyadh, Saudi Arabia. University of Maryland University College (UMUC) Working Paper Series, 2.

Molino, M., Dolce, V., Cortese, C. G., \& Ghislieri, C. (2018). Personality and Social Support as Determinants of Entrepreneurial Intention. Gender Differences in Italy. PLoS ONE, 13, e0199924. https://doi.org/10.1371/journal.pone.0199924

Muhammad, N., Warren, L., \& Binte-Saleem, S. (2017). Anything Can Happen, Anytime: The Impact of Conflict on Women's Entrepreneurship in Pakistan. Journal of Developmental Entrepreneurship, 22, Article ID: 1750025. https://doi.org/10.1142/S108494671750025X

Muralidharan, E., \& Pathak, S. (2017). Informal Institutions and International Entrepreneurship. International Business Review, 26, 288-302. https://doi.org/10.1016/j.ibusrev.2016.07.006

Mustafa, M. J., Hernandez, E., Mahon, C., \& Chee, L. K. (2016). Entrepreneurial Intentions of University Students in an Emerging Economy: The Influence of University Support and Proactive Personality on Students' Entrepreneurial Intention. Journal of Entrepreneurship in Emerging Economies, 8, 162-179.

https://doi.org/10.1108/JEEE-10-2015-0058

Mwiya, B. M. K., Wang, Y., Kaulungombe, B., \& Kayekesi, M. (2018). Exploring Entrepreneurial Intention's Mediating Role in the Relationship between Self-Efficacy and Nascent Behaviour: Evidence from Zambia, Africa. Journal of Small Business and Enterprise Development, 26, 466-485. https://doi.org/10.1108/JSBED-03-2017-0083

Neneh, B. N. (2020). Entrepreneurial Passion and Entrepreneurial Intention: The Role of Social Support and Entrepreneurial Self-Efficacy. Studies in Higher Education, 1-17. https://doi.org/10.1080/03075079.2020.1770716

Newman, A., Obschonka, M., Schwarz, S., Cohen, M., \& Nielsen, I. (2019). Entrepreneurial Self-Efficacy: A Systematic Review of the Literature on Its Theoretical Foundations, Measurement, Antecedents, and Outcomes, and an Agenda for Future Research. Journal of Vocational Behavior, 110, 403-419. https://doi.org/10.1016/j.jvb.2018.05.012

Noguera, M., Alvarez, C., \& Urbano, D. (2013). Socio-Cultural Factors and Female Entrepreneurship. International Entrepreneurship and Management Journal, 9, 183-197. https://doi.org/10.1007/s11365-013-0251-x

Nowiński, W., Haddoud, M. Y., Lančarič, D., Egerová, D., \& Czeglédi, C. (2019). The Impact of Entrepreneurship Education, Entrepreneurial Self-Efficacy and Gender on Entrepreneurial Intentions of University Students in the Visegrad Countries. Studies in Higher Education, 44, 361-379. https://doi.org/10.1080/03075079.2017.1365359

Obschonka, M., Fisch, C., \& Boyd, R. (2017a). Using Digital Footprints in Entrepreneurship Research: A Twitter-Based Personality Analysis of Superstar Entrepreneurs and Managers. Journal of Business Venturing Insights, 8, 13-23.

https://doi.org/10.1016/j.jbvi.2017.05.005

Obschonka, M., Hakkarainen, K., Lonka, K., \& Salmela-Aro, K. (2017b). Entrepreneurship as a Twenty-First Century Skill: Entrepreneurial Alertness and Intention in the Transition to Adulthood. Small Business Economics, 48, 487-501.

https://doi.org/10.1007/s11187-016-9798-6

Omeihe, K. O., Dakhan, S. A., Khan, M. S., Gustafsson, V., \& Amoako, I. O. (2019). Riding the Wave: Understanding the Context of Female Entrepreneurship in Pakistan. In F. Tomos, N. Kumar, N. Clifton, \& D. Hyams-Ssekasi (Eds.), Women Entrepreneurs and Strategic Decision Making in the Global Economy (pp. 20-39). Hershey, PA: IGI Global. https://doi.org/10.4018/978-1-5225-7479-8.ch002 
Paoloni, P., \& Serafini, G. (2018). Female Entrepreneurship in Perspective: A Methodological Issue. Administrative Sciences, 8, 67. https://doi.org/10.3390/admsci8040067

Pergelova, A., Manolova, T., Simeonova-Ganeva, R., \& Yordanova, D. (2019). Democratizing Entrepreneurship? Digital Technologies and the Internationalization of Female-Led SMEs. Journal of Small Business Management, 57, 14-39. https://doi.org/10.1111/jsbm.12494

Pruett, M., Shinnar, R., Toney, B., Llopis, F., \& Fox, J.. (2009). Explaining Entrepreneurial Intentions of University Students: A Cross-Cultural Study. International Journal of Entrepreneurial Behavior \& Research, 15, 571-594. https://doi.org/10.1108/13552550910995443

Ratten, V. (2016). Female Entrepreneurship and the Role of Customer Knowledge Development, Innovation Outcome Expectations and Culture on Intentions to Start Informal Business Ventures. International Journal of Entrepreneurship and Small Business, 27, 262-272. https://doi.org/10.1504/IJESB.2016.073977

Roxas, B. G., Cayoca-Panizales, R., \& de Jesus, R. M. (2008). Entrepreneurial Knowledge and Its Effects on Entrepreneurial Intentions: Development of a Conceptual Framework. Asia-Pacific Social Science Review, 8, 61-77.

Roy, R., \& Das, N. (2019). A Critical Comparison of Factors Affecting Science and Technology Students' Entrepreneurial Intention: A Tale of Two Genders. International Journal for Educational and Vocational Guidance, 20, 49-77. https://doi.org/10.1007/s10775-019-09393-4

Saebi, T., Foss, N. J., \& Linder, S. (2019). Social Entrepreneurship Research: Past Achievements and Future Promises. Journal of Management, 45, 70-95. https://doi.org/10.1177/0149206318793196

Saeed, S., Yousafzai, S. Y., Yani-De-Soriano, M., \& Muffatto, M. (2015). The Role of Perceived University Support in the Formation of Students' Entrepreneurial Intention. Journal of Small Business Management, 53, 1127-1145. https://doi.org/10.1111/jsbm.12090

Sahban, M. A., Ramalu, S. S., \& Syahputra, R. (2016). The Influence of Social Support on Entrepreneurial Inclination among Business Students in Indonesia. Information Management and Business Review, 8, 32-46. https://doi.org/10.22610/imbr.v8i3.1330

Samuel, Y. A., Ernest, K., \& Awuah, J. B. (2013). An Assessment of Entrepreneurship Intention among Sunyani Polytechnic Marketing Students. International Review of Management and Marketing, 3, 37-49.

Schmutzler, J., Andonova, V., \& Diaz-Serrano, L. (2019). How Context Shapes Entrepreneurial Self-Efficacy as a Driver of Entrepreneurial Intentions: A Multilevel Approach. Entrepreneurship Theory and Practice, 43, 880-920.

https://doi.org/10.1177/1042258717753142

Shahab, Y., Chengang, Y., Arbizu, A. D., \& Haider, M. J. (2019). Entrepreneurial Self-Efficacy and Intention: Do Entrepreneurial Creativity and Education Matter? International Journal of Entrepreneurial Behavior \& Research, 25, 259-280. https://doi.org/10.1108/IJEBR-12-2017-0522

Shi, L., Yao, X., \& Wu, W. (2019). Perceived University Support, Entrepreneurial Self-Efficacy, Heterogeneous Entrepreneurial Intentions in Entrepreneurship Education: The Moderating Role of the Chinese Sense of Face. Journal of Entrepreneurship in Emerging Economies, 12, 205-230. https://doi.org/10.1108/JEEE-04-2019-0040

Shiri, N., Mohammadi, D., \& Hosseini, S. M. (2012). Entrepreneurial Intention of Agricultural Students: Effects of Role Model, Social Support, Social Norms and Perceived Desirability. Archives of Applied Science Research, 4, 892-897. 
Sieger, P., \& Minola, T. (2017). The Family's Financial Support as a "Poisoned Gift": A Family Embeddedness Perspective on Entrepreneurial Intentions. Journal of Small Business Management, 55, 179-204. https://doi.org/10.1111/jsbm.12273

Stroe, S., Parida, V., \& Wincent, J. (2018). Effectuation or Causation: An fsQCA Analysis of Entrepreneurial Passion, Risk Perception, and Self-Efficacy. Journal of Business Research, 89, 265-272. https://doi.org/10.1016/j.jbusres.2018.01.035

Tsai, K.-H., Chang, H.-C., \& Peng, C.-Y. (2016). Extending the Link between Entrepreneurial Self-Efficacy and Intention: A Moderated Mediation Model. International Entrepreneurship and Management Journal, 12, 445-463.

https://doi.org/10.1007/s11365-014-0351-2

Uchenna, E. B., Sanjo, O. M., \& Joseph, F. (2019). Entrepreneurial Orientation and Micro, Small and Medium Enterprises (MSMEs) Performance in Abia State, Nigeria. Covenant Journal of Entrepreneurship (Special Edition), 3, 19-35.

Wang, J.-H., Chang, C.-C., Yao, S.-N., \& Liang, C. (2016). The Contribution of Self-Efficacy to the Relationship between Personality Traits and Entrepreneurial Intention. Higher Education, 72, 209-224. https://doi.org/10.1007/s10734-015-9946-y

Welter, F., \& Kolb, S. (2006). Women and Entrepreneurship in Latvia. Telia Sonera Institute Discussion Paper, 4.

Wilson, F., Kickul, J., Marlino, D., Barbosa, S. D., \& Griffiths, M. D. (2009). An Analysis of the Role of Gender and Self-Efficacy in Developing Female Entrepreneurial Interest and Behavior. Journal of Developmental Entrepreneurship, 14, 105-119. https://doi.org/10.1142/S1084946709001247

Wu, J., Li, Y., \& Zhang, D. (2019). Identifying Women's Entrepreneurial Barriers and Empowering Female Entrepreneurship Worldwide: A Fuzzy-Set QCA Approach. International Entrepreneurship and Management Journal, 15, 905-928.

https://doi.org/10.1007/s11365-019-00570-z 